Article

\title{
Effect of Different Cooking Methods on Folate Content in Chicken Liver
}

\author{
Marta Czarnowska-Kujawska ${ }^{1, *}$, Anna Draszanowska ${ }^{2}$ and Elżbieta Gujska ${ }^{1}$ \\ 1 Department of Commodity and Food Analysis, The Faculty of Food Sciences, University of Warmia and \\ Mazury in Olsztyn, 10-726 Olsztyn, Poland; elka@uwm.edu.pl \\ 2 Department of Human Nutrition, The Faculty of Food Sciences, University of Warmia and Mazury in \\ Olsztyn, 10-718 Olsztyn, Poland; anna.draszanowska@uwm.edu.pl \\ * Correspondence: marta.czarnowska@uwm.edu.pl; Tel.: +48-89-524-52-76
}

Received: 2 September 2020; Accepted: 2 October 2020; Published: 9 October 2020

check for updates

\begin{abstract}
Common liver sources in European countries include cow, chicken, duck, lamb and pig. Despite its decreasing popularity, liver is possibly one of the most nutrient-dense foods, being rich in high-quality protein and low in calories. In animals, the liver is the storage organ for folate. In this study, the effect of different cooking methods on folate vitamers content in chicken liver was investigated. Three folate derivatives, 5- $\mathrm{CH}_{3}-\mathrm{H}_{4}$ PteGlu, $\mathrm{H}_{4}$ PteGlu and 5-HCO-H 4 PteGlu, were identified in the analyzed samples using high performance liquid chromatography (HPLC). The folate content in liver after sous-vide $\left(60{ }^{\circ} \mathrm{C} / 75 \mathrm{~min}\right)$ and steaming $\left(100{ }^{\circ} \mathrm{C} / 30 \mathrm{~min}\right) \mathrm{did}$ not differ significantly $(p \leq 0.05)$ from raw liver folate content $(781 \mu \mathrm{g} / 100 \mathrm{~g})$. Even liver cooked in a combi oven or grilled (which resulted in significant folate losses) showed much higher folate content, 455-631 $\mu \mathrm{g} / 100 \mathrm{~g}$ and 612-715 $\mu \mathrm{g} / 100 \mathrm{~g}$, respectively, than the most folate-abundant plant foods. These findings are important as they demonstrate that processed liver has the potential to improve the supply of folate and meet the recommended daily requirements, particularly when folate deficiency is common worldwide.
\end{abstract}

Keywords: folic acid; folate; vitamin B; food composition; animal liver; cooking methods; sous-vide; steaming; combi oven; HPLC

\section{Introduction}

B-vitamin folic acid exists naturally in foods in polyglutamyl forms, of which the most common are tetrahydrofolate, 5-methyltetrahydrofolate and 5-formyltetrahydrofolate. Folic acid is the most stable form in terms of chemical degradation and the most bioavailable and therefore is used for both fortification and supplementation purposes [1,2]. Folate vitamers are thought to play a crucial role in the prevention of many diseases, including neural tube defects [3], megaloblastic anemia [4], cardiovascular disease [5] and some types of cancers (colorectal and colon) [6,7]. Other health problems related to common folate deficiency may include neurocognitive decline in the elderly [8]. Due to the increased recognition of the potential protective role of folate in the above-mentioned health problems, the European Food Safety Authority established a Population Reference Intake for folate at the level of $330 \mu \mathrm{g} /$ day, and of $600 \mu \mathrm{g} /$ day during pregnancy or lactation (or for women planning pregnancy) [9]. To meet the recommendation, the most folate-deficient groups (pregnant women or the elderly) are advised to folic acid supplementation. Some countries, such as the US and Canada, have introduced mandatory folic acid fortification of cereal-grain products [10]. Since European countries, due to safety concerns regarding excess folic acid intake (for instance, for vitamin $B_{12}$ deficiency in the elderly) [11], are reluctant to introduce obligatory folic acid fortification, alternative approaches to achieve optimal folate status need to be considered [12]. Recent studies promote the consumption of 
folate-enriched foods like eggs and bread along with the addition of folate-abundant plants [12,13]; moreover, promising but still not popular products, like tropical fruits, have the potential to improve the supply of this critical vitamin [14]. Blancquaert et al. [15] summarized the folate biofortification efforts in crops, lettuce, tomato and potato through metabolic engineering.

Meanwhile, a rich natural source of folate, but often ignored, is animal liver. The once popular liver has been considered to be unhealthy, high in fat, with carcinogenic potential and it became less common than muscle meats, which now tend to be favored by most consumers. Liver, apart from being cheap and widely available, is also an important source of several micronutrients. An amount of $100 \mathrm{~g}$ of cooked beef liver provides more than the RDI (recommended daily intake) for vitamin $\mathrm{B}_{12}$, vitamin $\mathrm{A}$, riboflavin and copper. It is also a rich source of choline and iron [16-20]. However, liver is also the storage organ for most folate in the body [21] which results in a large amount of this vitamin in a liver portion compared to most folate-abundant plant origin sources, such as broccoli, spinach or legumes [20,22-25]. According to Winkles et al. [26], folate derived from liver also has high aggregate bioavailability (approximately 80\%), same as that from vegetables and fruit. The previous recommendation to avoid liver consumption has been overturned by recent studies showing bovine liver to be almost free of substances of very high concern such as heavy metals $[27,28]$.

The available literature on the folate content in the most common sources of liver (beef, chicken and pork) are scarce and differ widely. For dietary recommendations, it is important to have appropriate information on the availability of nutrients in any food product as well as the effect of different processing methods on their retention. The current study aimed to determine the stability of folate vitamers in chicken liver using validated HPLC methods following preparation with different techniques of culinary treatment such as sous-vide, steaming, combi oven, and grilling.

\section{Materials and Methods}

\subsection{Samples}

The chicken liver was purchased at the poultry slaughterhouse on the day of slaughter and conducted to different heating treatment as shown in Table 1. For each treatment, 3 portions $(3 \times 500 \mathrm{~g})$ of fresh rinsed and dried liver were processed. Then samples were blended (Robot Coupe Mini MP 190 v.v.; Montceau-en-Bourgogne, France) and $200 \mathrm{~g}$ of sub-sample was taken for the determination of folate content.

\subsection{Reagents, Standards and Enzymes}

All reagents used were of analytical grade, apart from methanol and acetonitrile which were of HPLC grade. Water was purified using Mili-Q system (Millipore; Vienna, Austria). Folate standards, folic acid (PteGlu), 5-methyltetrahydrofolate (5- $\left.\mathrm{CH}_{3}-\mathrm{H}_{4} \mathrm{PteGlu}\right)$, 5-formyltetrahydrofolate (5-HCO- $\left.\mathrm{H}_{4} \mathrm{PteGlu}\right)$ and tetrahydrofolate $\left(\mathrm{H}_{4} \mathrm{PteGlu}\right)$ were obtained from Sigma Aldrich (St. Louis, MO, USA); 10-formylfolic acid (10-HCO-H $\left.\mathrm{H}_{4} \mathrm{PteGlu}\right)$ and 5,10-methenyltetrahydrofolate $\left(5,10-\mathrm{CH}^{+}-\mathrm{H}_{4}\right.$ PteGlu) were obtained from Schircks Laboratories (Jona, Switzerland). Standards were all prepared as described by Konings [29]. 10-formyldihydrofolate $\left(10-\mathrm{HCO}-\mathrm{H}_{2} \mathrm{PteGlu}\right)$ was obtained from 5,10-methenyltetrahydrofolate according to Pfeiffer et al. [30]. Fresh rat plasma was purchased from Europa Bioproducts Ltd. (Cambridge, Great Britain), $\alpha$-amylase (E.C.3.2.1.1) and protease (E.C.3.4.24.31) from Sigma Aldrich.

\subsection{Sample Pretreatment}

The folate vitamers content was determined with the method described by Czarnowska-Kujawska et al. [25]. Samples were analyzed in triplicate as presented in Figure 1. Folate protection from oxidation during the sample pretreatment was provided by keeping the sample under subdued light, the use of nitrogen, and cooling in ice after heating. Sample extracts purification was carried out before HPLC analysis using Solid Phase Extraction (SPE) on Strong Anion Exchange (SAX) Bakerbond spe. JT cartridges 
(3 mL $\times 500 \mathrm{mg}$ Solid Phase Extraction Column, PP (polypropylene), Quaternary Amine $\left(\mathrm{N}^{+}\right)$Anion Exchange; Philipsburg, USA) as outlined by Jastrebova et al. [31]. Briefly, $4 \mathrm{~mL}$ of sample was inserted on preconditioned SAX column and eluted with $4 \mathrm{~mL}$ of elution buffer $(0.1 \mathrm{M}$ sodium acetate containing $10 \%$ $(w / v)$ sodium chloride and $0.1 \%(v / v)$ 2-mercaptoethanol).

Table 1. Heat treatment parameters of liver samples.

\begin{tabular}{|c|c|c|}
\hline Heat Treatment & Description & $\begin{array}{c}\text { Parameters } \\
\text { (Temperature/Time and } \\
\text { Humidity) }\end{array}$ \\
\hline 1. Sous-vide & \multirow{2}{*}{$\begin{array}{l}\text { Portions of liver were packaged individually in plastic bags with the } \\
\text { use of the Busch Edesa vacuum sealer (Montcada, Spain). The bags } \\
\text { were made of polyamide/polyethylene (PA/PE) with a thickness of } 52 \\
\mu \mathrm{m} \text {, and they were designed specifically for sous vide cooking (Hendi, } \\
\text { Austria). The samples were cooked in fusionchef Diamond Z } \\
\text { immersion circulator sous-vide cooker by Julabo (Seelbach, Germany). }\end{array}$} & $60{ }^{\circ} \mathrm{C} / 75 \mathrm{~min}$ \\
\hline 2. Sous-vide & & $75^{\circ} \mathrm{C} / 45 \mathrm{~min}$ \\
\hline 3. Oven, hot air and steam & \multirow{3}{*}{ Cooked in combi oven (Retional SCC WE 101; Landsberg, Germany). } & $\begin{array}{l}\text { hot air of } 180{ }^{\circ} \mathrm{C} \text { and } \\
\text { relative humidity of } \\
30 \% / 20 \mathrm{~min}\end{array}$ \\
\hline 4. Oven, hot air and steam & & $\begin{array}{l}\text { hot air of } 160{ }^{\circ} \mathrm{C} \text { and } \\
\text { relative humidity of } \\
50 \% / 30 \mathrm{~min}\end{array}$ \\
\hline 5. Oven, hot air & & $\begin{array}{l}100 \% \text { hot air of } 180^{\circ} \mathrm{C} / 30 \\
\min \end{array}$ \\
\hline 6. Oven, overheated steam & $\begin{array}{l}\text { Steamed with overheated steam in combi oven (Retional SCC WE 101; } \\
\text { Landsberg, Germany). }\end{array}$ & $100{ }^{\circ} \mathrm{C} / 30 \mathrm{~min}$ \\
\hline 7. Grill & Grilled without oil addition using Roch Guss (Italy) grill pan & $200-220^{\circ} \mathrm{C} / 4 \mathrm{~min}$ \\
\hline 8. Grill, oil addition & Grilled with rapeseed oil addition using Roch Guss (Italy) grill pan & $170-200{ }^{\circ} \mathrm{C} / 6 \mathrm{~min}$ \\
\hline
\end{tabular}

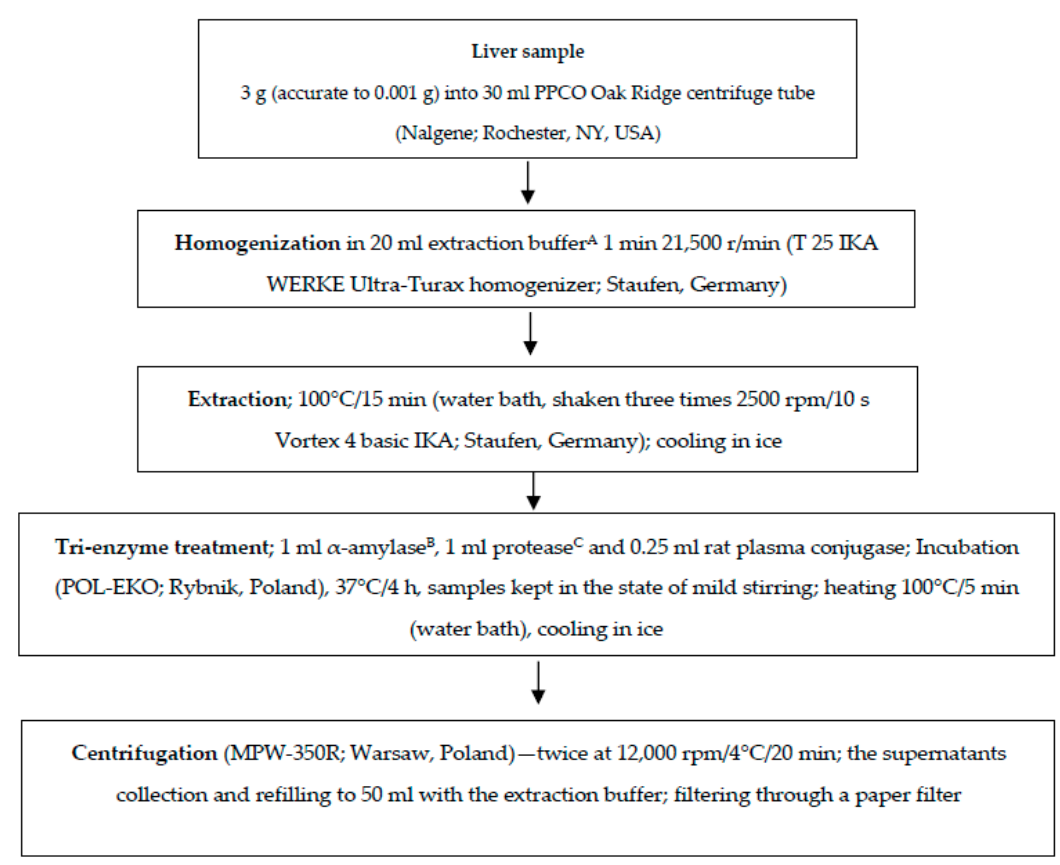

Figure 1. The sample preparation flow chart; ${ }^{\mathrm{A}}$ extraction buffer: $0.1 \mathrm{M}$ phosphate buffer $\mathrm{pH} 6.1$ with $1 \%(w / v)$ sodium ascorbate and $0.1 \%(v / v) 2$-mercaptoethanol; ${ }^{B} 1 \mathrm{~mL} \alpha$-amylase solution $(20 \mathrm{mg} / \mathrm{mL})$;

C $1 \mathrm{~mL}$ protease solution $(4 \mathrm{mg} / \mathrm{mL})$.

\subsection{HPLC Analysis}

The HPLC separation (Shimadzu Series LC-10A; Shimadzu Co.; Kyoto, Japan) of folate was conducted as described by Czarnowska and Gujska [32]. For separation, a Synergi 4u Hydro-RP 80A 
$(250 \times 4.6 \mathrm{~mm}) 4-\mu \mathrm{m}$ column was used (Phenomenex; Torrance, CA, USA). The total separation time was $41 \mathrm{~min}$. The gradient elution parameters were as briefly described: injection $50 \mu \mathrm{L}$, flow rate: $1 \mathrm{~mL} / \mathrm{min}$, column temperature $25^{\circ} \mathrm{C}$, fluorescence detection: 290-nm excitation and 360-nm emission and for 10-HCO-H ${ }_{4}$ PteGlu 360-nm excitation and 460-nm emission, UV detection: $290 \mathrm{~nm}$. The mobile phase was $30 \mathrm{mM}$ phosphoric acid buffer, $\mathrm{pH} 2.3$, and acetonitrile. The gradient started with 5\% acetonitrile and was maintained as such for the first $8 \mathrm{~min}$ until being raised to $17.5 \%$ within $17 \mathrm{~min}$. Peaks identification was based on standard retention times.

Quantification of the identified individual folate vitamers was based on fluorescence detection with the use of external multilevel $(n=8)$ calibration curves, linearity range of $0.3-66.3 \mathrm{ng} / \mathrm{mL}$ for $5-\mathrm{CH}_{3}-\mathrm{H}_{4} \mathrm{PteGlu}$ (the correlation coefficient $\left.>0.9994\right), 0.6-55.7 \mathrm{ng} / \mathrm{mL}$ for $\mathrm{H}_{4}$ PteGlu $(>0.9996)$ and 3-150 ng/mL for $5-\mathrm{HCOH}_{4}$ PteGlu (>0.9997). The limit of quantification (LOQ) was defined as the lowest analyte concentration yielding a signal-to-noise $(\mathrm{S} / \mathrm{N})$ ratio of 10 [31] and were at the level of 0.3 , 0.6 and $3.0 \mathrm{ng} / \mathrm{mL}$ for $5-\mathrm{CH}_{3}-\mathrm{H}_{4}$ PteGlu, $\mathrm{H}_{4}$ PteGlu and $5-\mathrm{HCO}-\mathrm{H}_{4}$ PteGlu, respectively.

\subsection{Statistical Analysis}

The presented results of folate derivatives content in analyzed samples are all based on the fresh weight (FW) and were demonstrated as means with standard deviations from three repetitions. The given total folate content is presented as the sum of $\mathrm{H}_{4} \mathrm{PteGlu}, 5-\mathrm{CH}_{3}-\mathrm{H}_{4} \mathrm{PteGlu}$, and $5-\mathrm{HCO}-\mathrm{H}_{4}$ PteGlu contents calculated to folic acid with the use of molar absorption coefficient given by Blakely [33]. Differences in the total folate content in raw chicken liver and after different processing methods were compared using Duncan multiple range test, with the significance level at $p<0.05$. Statistical analysis was carried out using Statistica software version 10.0 (StatSoft; Cracow, Poland).

\subsection{Method Validation}

The results for the validation of the HPLC method for folate determination in liver samples were described in the previous article by Czarnowska-Kujawska et al. [25]. Recovery tests were conducted by analyzing spiked control samples of chicken and pig livers with known amounts of $\mathrm{H}_{4}$ PteGlu, 5- $\mathrm{CH}_{3}-\mathrm{H}_{4} \mathrm{PteGlu}$, and 5- $\mathrm{HCO}-\mathrm{H}_{4}$ PteGlu prior to extraction. Then, the spiked samples were processed through the entire analytical procedure of sample preparation. The recovery $(R)$ was calculated as $R=\left(C_{\text {found }}-C_{\text {sample }}\right) / C_{\text {added }}$, where $C_{\text {found }}$ is concentration in spiked sample, $C_{\text {sample }}$ is the concentration in the sample before spiking and $\mathrm{C}_{\text {added }}$ is the concentration of the added standard. The mean recovery $(n=10)$ was $95 \% \pm 7 \%$ for $5-\mathrm{CH}_{3}-\mathrm{H}_{4} \mathrm{PteGlu}, 91 \% \pm 8 \%$ for $\mathrm{H}_{4} \mathrm{PteGlu}$ and $88 \% \pm 9 \%$ for $5-\mathrm{HCO}-\mathrm{H}_{4}$ PteGlu. The repeatability of the analytical treatment was checked with the use of a certified reference material (BCR-487 Pig Liver (vitamins), Joint Research Center; Geel, Belgium) on different extraction days. The obtained total folate value was $12.76 \pm 0.61 \mathrm{mg} / \mathrm{kg}$ and the mean of $5-\mathrm{CH}_{3}-\mathrm{H}_{4}$ PteGlu was $3.12 \pm 0.43 \mathrm{mg} / \mathrm{kg}$. The given results were well in line with the certified amounts of $2.6 \mathrm{mg} / \mathrm{kg}$ for $5-\mathrm{CH}_{3}-\mathrm{H}_{4}$ PteGlu and $13.3 \pm 1.3 \mathrm{mg} / \mathrm{kg}$ for the total folate.

\section{Results and Discussion}

The folate content of raw and processed chicken liver obtained with the HPLC method is presented in Table 2. Three folate forms were identified in liver samples: $\mathrm{H}_{4}$ PteGlu, $5-\mathrm{CH}_{3}-\mathrm{H}_{4}$ PteGlu and $5-\mathrm{HCO}-\mathrm{H}_{4}$ PteGlu. The methyl form was found to be the dominant folate form in all samples, which is in agreement with previously published data for animal livers [25,34]. The total folate value in raw chicken liver was $781 \mu \mathrm{g} / 100 \mathrm{~g}$ and was lower than the value previously reported for chicken and turkey raw livers, 1077 and $1078 \mu \mathrm{g} / 100 \mathrm{~g}$, respectively, but still higher than for pig and beef raw livers, 554 and $508 \mu \mathrm{g} / 100 \mathrm{~g}$, respectively [25]. The obtained result was higher than the total folate content given in the Food Data Central of U.S. Department of Agriculture for raw livers of chicken, $588 \mu \mathrm{g} / 100 \mathrm{~g}$, turkey, $677 \mu \mathrm{g} / 100 \mathrm{~g}$, and beef, $290 \mu \mathrm{g} / 100 \mathrm{~g}$ [20]. 
Table 2. Folate content in raw and processed chicken liver ( $\mu \mathrm{g} / 100 \mathrm{~g}$ fresh weight $(\mathrm{FW})$ ).

\begin{tabular}{|c|c|c|c|c|}
\hline Method of Heat Treatment & $\mathrm{H}_{4}$ PteGlu & 5- $\mathrm{CH}_{3}-\mathrm{H}_{4}$ PteGlu & 5-HCO-H $\mathrm{H}_{4}$ PteGlu & $\begin{array}{c}\text { Total Folate } \\
\text { (as Folic Acid) }\end{array}$ \\
\hline Raw sample & $243^{1} \pm 23$ & $505 \pm 41$ & $57 \pm 4$ & $781 \pm 64^{\text {a } 2}$ \\
\hline Sous-vide $60^{\circ} \mathrm{C} / 75 \mathrm{~min}$ & $48 \pm 2$ & $677 \pm 13$ & $51 \pm 1$ & $749 \pm 14^{\mathrm{ab}}$ \\
\hline Sous-vide $75^{\circ} \mathrm{C} / 45 \mathrm{~min}$ & $126 \pm 10$ & $490 \pm 13$ & $60 \pm 1$ & $654 \pm 18^{c}$ \\
\hline Oven, $180^{\circ} \mathrm{C} / 20 \mathrm{~min}, 30 \%$ humid. & $98 \pm 6$ & $482 \pm 18$ & $73 \pm 3$ & $631 \pm 24^{c}$ \\
\hline Oven, $160{ }^{\circ} \mathrm{C} / 30 \mathrm{~min}, 50 \%$ humid. & $4 \pm 1$ & $457 \pm 37$ & $94 \pm 7$ & $534 \pm 41^{\mathrm{d}}$ \\
\hline Oven, $100 \%$ hot air, $180{ }^{\circ} \mathrm{C} / 30 \mathrm{~min}$ & $11 \pm 1$ & $371 \pm 27$ & $92 \pm 10$ & $455 \pm 26^{\mathrm{e}}$ \\
\hline Oven, steam $100^{\circ} \mathrm{C} / 30 \mathrm{~min}$ & $100 \pm 5$ & $627 \pm 10$ & $82 \pm 5$ & $780 \pm 17^{\mathrm{a}}$ \\
\hline Grill $200-220^{\circ} \mathrm{C} / 4 \mathrm{~min}$ & $3 \pm 1$ & $657 \pm 9$ & $83 \pm 6$ & $715 \pm 12^{b}$ \\
\hline Grill, oil addition $170-200^{\circ} \mathrm{C} / 6 \mathrm{~min}$ & $11 \pm 1$ & $556 \pm 37$ & $69 \pm 5$ & $612 \pm 32^{c}$ \\
\hline
\end{tabular}

In the present study, chicken liver samples were prepared using sous-vide cooking, cooking in a combi oven and steaming and grilling with and without an oil addition. Two main mechanisms are described as being involved in folate losses, leaching into the surrounding liquid and oxidation during heat treatment [35]. The effect of different processing methods on folate content using the most common plant origin sources, such as legumes, grain products, green leafy and other vegetables, has been studied in recent years [32,36-40]. Delchier et al. [41] reviewed folate content and stability in fruit and vegetables under most studied processes such as boiling, blanching, steaming, freezing, canning and juicing. High folate losses were observed, inter alia, after canning (from $65 \%$ for spinach to $77 \%$ for chickpeas), boiling (from $25 \%$ for green peas to $70 \%$ for chickpeas) and blanching with the highest losses found for spinach (on average from $50 \%$ to $95 \%$ for hashed spinach). Bureau et al. [39] studied vegetable samples and found no significant folate losses after steaming or microwave heating. None of the thermal treatments applied in the present study caused as drastic folate losses as in the examples of vegetable processing mentioned before and none of the samples had losses exceeding $45 \%$. Moreover, in 5 out of 8 applied treatments, the total folate loss did not exceed $25 \%$. Sous-vide and the combi oven cooking method deserve special attention since there is a lack of data on the effect of these increasingly popular cooking techniques on the folate contents in both plant and animal origin samples. In the sous-vide technique, meat is vacuum-packaged and subjected to heating in a water bath at temperatures lower than in traditional heating treatment. Multi-layer, non-gas-permeable plastic packaging, which is also resistant to high temperature, minimizes the loss of nutrients and water and protects vitamins from degradation during exposure to high temperatures [42]. Moreover, it enables obtaining more juicy, tender and flavorful meat and fish products than high-temperature cooking methods $[43,44]$. In the current study, sous-vide cooking performed at a lower temperature $\left(60^{\circ} \mathrm{C}\right)$, but for a longer time $(75 \mathrm{~min})$, did not cause significant $(p<0.05)$ folate losses compared with raw liver (Table 2). However, raising the temperature to $75^{\circ} \mathrm{C}$ and reducing the time of sous-vide cooking to $45 \mathrm{~min}$ resulted in a significant (16\%) loss of folate. Steaming performed at $100{ }^{\circ} \mathrm{C}$ for $30 \mathrm{~min}$ (higher than in the sous-vide method) did not cause significant folate reduction. Steaming was conducted in the oven chamber by steam injection. This technique is increasingly being used in meat processing since it reduces the time of thermal treatment and provides juicier meat products by protecting the product from dehydration of the surface compared to heating in dry air [45-47]. Peterson [48] studied the influence of sous-vide processing, steaming and boiling on folate retention in broccoli florets and observed higher folate losses ( $89 \%$ retention of folate in sous-vide compared with $59 \%$ for steaming and $25 \%$ for boiling, all at $100{ }^{\circ} \mathrm{C} / 40 \mathrm{~min}$ ).

A combination of moist heat, dry heat and dry heat separately were used in other treatments using the combi oven cooking method. This relatively new cooking technique, which uses a single piece of equipment, can replace cooking needs for a steamer, grill and convection oven. Its increasing use in foodservice results from reduced cooking time and cooking loss, yielding a juicier product with good control of relative moisture and cooking climate. It preserves food quality, including appearance, 
flavor and nutrients [49]. In the current study, all treatment using hot, dry heat caused significant folate losses. The highest folate reduction (more than $40 \%$ ) was observed when $100 \%$ dry air at $180{ }^{\circ} \mathrm{C}$ was applied for $30 \mathrm{~min}$. Lowering the temperature to $160{ }^{\circ} \mathrm{C}$ and then applying $50 \%$ relative humidity for the remaining $30 \mathrm{~min}$ of cooking time resulted in a lower loss of folate (30\% less). Only $20 \%$ reduction was observed when the cooking time was reduced to $20 \mathrm{~min}$ and the temperature was increased to $180{ }^{\circ} \mathrm{C}$ and relative humidity was at the level of $30 \%$. The obtained results for the combi oven cooking method indicate that the heating time might be a more important factor (in terms of folate in chicken liver) than temperature change $\left(160-180^{\circ} \mathrm{C}\right)$ and different relative humidity proportions applied (0-50\%). In grilled chicken liver, a higher grilling temperature $\left(200-220^{\circ} \mathrm{C}\right.$ for $\left.4 \mathrm{~min}\right)$ resulted in lower folate losses of only $8 \%$ compared with grilling with an oil addition (22\%). Oil-free treatment thanks to shorter grilling time, resulted in less leaching of ingredients and less water evaporation. In the second grilling treatment, the addition of oil caused a lower temperature $\left(170-200{ }^{\circ} \mathrm{C}\right)$ and extended the grilling time to $6 \mathrm{~min}$ and resulted in higher folate losses (22\%). A previous study by Aramouni and Godber [50] on folate stability in beef liver under cooking and frozen storage, showed higher folate losses after grilling and frying ( $41 \%$ and $50 \%$, respectively).

The results presented in Table 2 were also used to analyze the stability of individual folate vitamers in chicken liver samples due to the applied heating method. The current observations are in agreement with the findings of other authors summarized by Delchier et al. [41], that different folate vitamers have markedly different stabilities, with $\mathrm{H}_{4}$ PteGlu to be the least stable under different processing conditions. In the current study, the $\mathrm{H}_{4}$ PteGlu content in raw liver was $243 \mu \mathrm{g} / 100 \mathrm{~g}$. The lowest reduction of this folate form (not exceeding $60 \%$ ) was observed in sous-vide $\left(75^{\circ} \mathrm{C} / 45 \mathrm{~min}\right)$, steaming and combi cooking with hot air $\left(180^{\circ} \mathrm{C}\right)$ and a relative humidity of $30 \%$ for $20 \mathrm{~min}$. In other cooking methods, the losses ranged from $80 \%$ to $99 \%$. The $5-\mathrm{CH}_{3}-\mathrm{H}_{4}$ PteGlu initial content of $505 \mu \mathrm{g} / 100 \mathrm{~g}$ in raw liver was only slightly reduced by no more than $10 \%$ in sous-vide $\left(75^{\circ} \mathrm{C} / 45 \mathrm{~min}\right)$, combi cooking of $180{ }^{\circ} \mathrm{C}$ and relative humidity of $30 \% / 20 \mathrm{~min}$ and combi cooking of $160^{\circ} \mathrm{C}$ and a relative humidity of $50 \% / 30 \mathrm{~min}$. Combi cooking with $100 \%$ hot air of $180^{\circ} \mathrm{C}$ for 30 min caused a methyl folate form reduction of nearly $30 \%$. In the liver samples grilled with an oil addition grilled and steamed and cooked with sous-vide ( $60{ }^{\circ} \mathrm{C} / 75 \mathrm{~min}$ ), $5-\mathrm{CH}_{3}-\mathrm{H}_{4}$ PteGlu increased from $10 \%$, in grilled with oil, to nearly $35 \%$ in the sous-vide method. Vahteristo et al. The authors in [22] found an increase (up to 136\%) in the 5- $\mathrm{CH}_{3}-\mathrm{H}_{4} \mathrm{PteGlu}$ content in rainbow trout sample after heating. This could result from enzymatic interconversions in fresh liver while preparing the sample for analysis or during the methylation reaction while frying [22]. For $5-\mathrm{HCO}-\mathrm{H}_{4}$ PteGlu, which was the least present form in raw liver $(57 \mu \mathrm{g} / 100 \mathrm{~g})$, its content reduction was observed only after sous-vide treatment conducted at $60{ }^{\circ} \mathrm{C}$ for $75 \mathrm{~min}$. After other processing methods, an unexpected increase of up to $65 \%$ in combi oven cooking with hot air of $160{ }^{\circ} \mathrm{C}$ and relative humidity of $50 \%$ for $30 \mathrm{~min}$ was observed. The explanation for this could be the higher stability of 5-HCO- $\mathrm{H}_{4}$ PteGlu compared with $\mathrm{H}_{4}$ PteGlu and $5-\mathrm{CH}_{3}-\mathrm{H}_{4}$ PteGlu under different conditions and spontaneous interconversion, either in the food or during analysis [41].

In general, both raw and processed chicken livers were characterized by very high folate content. The current results indicate that even liver samples with significant folate losses (as a result of the applied heat treatment) still had much higher folate content compared to commonly consumed natural folate sources, mainly of plant origin. Table 3 presents a comparison of the results of folate content for processed chicken liver with the literature data for examples of various food samples. 
Table 3. Folate content in raw and processed food samples ( $\mu \mathrm{g} / 100 \mathrm{~g}$ FW).

\begin{tabular}{|c|c|c|}
\hline Food Sample & Folate Content & Reference \\
\hline Processed chicken liver & $455-780$ & Own study \\
\hline Butterhead lettuce & 71 & [51] \\
\hline Rocket in protective atmosphere, rinsed & 198 & \\
\hline Fresh broccoli & 159 & [32] \\
\hline Frozen broccoli & 143 & \\
\hline Fresh cauliflower & 89 & \\
\hline Frozen cauliflower & 82 & \\
\hline Raw French bean & 132 & {$[52]$} \\
\hline Boiled French bean & 48 & \\
\hline Faba beans dried & 96 & [53] \\
\hline Faba beans canned & 18 & \\
\hline Raw chickpeas & 226 & [38] \\
\hline Soaked chickpeas & 343 & \\
\hline Blanched chickpeas & 271 & \\
\hline Baker's yeast & 874 & [13] \\
\hline Wheat flour & 48 & \\
\hline Fresh spinach & 238 & \\
\hline $40 \mathrm{~g} / 100 \mathrm{~g}$ spinach fortified whole-grain bread & 117 & \\
\hline Fresh rye bread & 83 & [36] \\
\hline Raw whole fruit guavas (tropical fruit) & 91 & [14] \\
\hline Jack fruit chips (tropical fruit) & 192 & \\
\hline Banana & 13 & [54] \\
\hline Strawberry & 80 & [53] \\
\hline Sweet potato & 22 & \\
\hline Raw folate-enriched eggs & 135 & [12] \\
\hline Folate-enriched eggs after 3 min boiling & 125 & \\
\hline
\end{tabular}

\section{Conclusions}

The present study provides a better understanding of the effect of different cooking methods on folate content in animal liver, confirming the different stability levels of various folate vitamers. Both raw and processed chicken liver were shown to be rich natural sources of folate. The current study found that the consumption of the processed liver should be encouraged, especially due to common folate deficiency and controversy surrounding excess synthetic folic acid consumption. Additionally, in terms of food preparation, sous-vide $\left(60^{\circ} \mathrm{C} / 75 \mathrm{~min}\right)$, steaming and grilling can be recommended for liver preparation in households or food services as an ideal way to maintain maximum folate retention.

The obtained results inspire further research to provide information on the effect of the different cooking methods on other quality parameters of different animal livers such as lipid profile, cholesterol, color, lipid oxidation or another bioactive ingredients content in order to evaluate the overall effect on the product.

Author Contributions: M.C.-K. performed the experiment, methodology and validation, data analysis, review and writing - original draft preparation, project administration and funding acquisition; A.D. performed the experiment, methodology, writing — review and editing; E.G.—writing—review and editing. All authors have read and agreed to the published version of the manuscript.

Funding: This research was funded by Minister of Science and Higher Education in the range of the program entitled "Regional Initiative of Excellence" for the years 2019-2022, Project No. 010/RID/2018/19, amount of funding 12.000.000 PLN and University of Warmia and Mazury funds Theme No. 17.610.008-300.

Conflicts of Interest: The authors declare no conflict of interest. 


\section{References}

1. Gregory, J.F. Chemical and nutritional aspects of folate research, analytical procedures, methods of folate synthesis, stability, and bioavailabilty of dietary folates. Adv. Food Nutr. Res. 1989, 33, 1-101. [CrossRef] [PubMed]

2. Dang, J.; Arcot, J.; Shrestha, A. Folate retention in selected processed legumes. Food Chem. 2000, 68, $295-298$. [CrossRef]

3. Czeizel, A.E.; Dudas, I. Prevention of the first occurrence of neural-tube defects by periconceptional vitamin supplementation. JAMA 1992, 327, 1832-1835. [CrossRef]

4. Beck, W.S. Diagnosis of megaloblastic-anemia. Annu. Rev. Med. 1991, 42, 311-322. [CrossRef] [PubMed]

5. Robinson, K. Homocysteine, B vitamins, and risk of cardiovascular disease. Heart 2000, 83, 127-130. [CrossRef] [PubMed]

6. Kim, Y.I. Folate and colorectal cancer: An evidence-based critical review. Mol. Nutr. Food Res. 2007, 51, 267-292. [CrossRef]

7. Lee, J.E.; Chan, A.T. Fruit, vegetables, and folate: Cultivating the evidence for cancer prevention. Gastroenterology 2011, 141, 16-20. [CrossRef]

8. Morris, M.S.; Jacques, P.F.; Rosenberg, I.H.; Selhub, J. Folate and vitamin B-12 status in relation to anemia, macrocytosis, and cognitive impairment in older, Americans in the age of folic acid fortification. Am. J. Clin. Nutr. 2007, 85, 193-200. [CrossRef]

9. EFSA. Panel on dietetic products, nutrition and allergies. Scientific opinion on dietary reference values for folate. EFSA J. 2014, 12, 3893-3952.

10. Jacques, P.F.; Selhub, J.; Bostom, A.G.; Wilson, P.W.; Rosenberg, I.H. The effect of folic acid fortification on plasma folate and total homocysteine concentrations. New Engl. J. Med. 1999, 340, 1449-1454. [CrossRef]

11. Savage, D.G.; Lindenbaum, J. Folate-cobalamin interactions. In Folate in Health and Disease; Bailey, L.B., Ed.; Marcel Dekker Inc.: New York, NY, USA, 1995; pp. 237-285.

12. Altic, L.; McNulty, H.; Hoey, L.; McAnena, L.; Pentieva, K. Validation of Folate-Enriched eggs as a functional food for improving folate intake in consumers. Nutrients 2016, 8, 777. [CrossRef] [PubMed]

13. López-Nicolás, R.; Frontela, C.; González-Abellán, R.; Barado-Piqueras, A.; Perez-Conesa, D.; Gaspar, R. Folate fortification of white and whole-grain bread by adding Swiss chard and spinach. Acceptability by consumers. LWT-Food Sci. Technol. 2014, 59, 263-269. [CrossRef]

14. Striegel, L.; Weber, N.; Dumler, C.; Chebib, S.; Netzel, M.E.; Sultanbawa, Y.; Rychlik, M. Promising tropical fruits high in folates. Foods 2019, 8, 363. [CrossRef]

15. Blancquaert, D.; De Steur, H.; Gellynck, X.; Van Der Straeten, D. Present and future of folate biofortification of crop plants. J. Exp. Bot. 2014, 65, 895-906. [CrossRef] [PubMed]

16. National Institutes of Health. Office of Dietary Supplements. Vitamine B12. Fact Sheet for Health Professionals. 2017. Available online: https://ods.od.nih.gov/factsheets/VitaminB12-HealthProfessional/ (accessed on 20 May 2020).

17. National Institutes of Health. Office of Dietary Supplements. Vitamine, A. Fact Sheet for Health Professionals. 2017. Available online: https:/ods.od.nih.gov/factsheets/VitaminA-HealthProfessional/ (accessed on 20 May 2020).

18. National Institutes of Health. Office of Dietary Supplements. Riboflavin. Fact Sheet for Health Professionals. 2017. Available online: https://ods.od.nih.gov/factsheets/Riboflavin-HealthProfessional/ (accessed on 20 May 2020).

19. National Institutes of Health. Office of Dietary Supplements. Iron. Fact Sheet for Health Professionals. 2017. Available online: https://ods.od.nih.gov/factsheets/Iron-HealthProfessional/ (accessed on 13 August 2018).

20. USDA, United States Department of Agriculture, Agriculture Research Service. National Nutrient Database for Standard Reference Legacy Release. 2018. Available online: https://fdc.nal.usda.gov/fdc (accessed on 27 February 2020).

21. Bailey, L.B. Evaluation of a new recommended dietary allowances for folate. J. Am. Diet. Assoc. 1992, 92, 463-468.

22. Vahteristo, L.T.; Lehikoinen, K.E.; Ollilainen, V.; Koivistoinen, P.E.; Varo, P. Oven-baking and frozen storage affect folate vitamer retention. LWT-Food Sci. Technol. 1998, 31, 329-333. [CrossRef] 
23. Okholm-Hansen, B.; Brogren, C.H. Contents of Folacin in Foods; Levnedsmiddelstyrelsen: Copenhagen, Denmark, 1991. (In Danish)

24. Indyk, H.E.; Woollard, D.C. Single laboratory validation of an optical biosensor method for the determination of folate in foods. J. Food Compos. Anal. 2013, 29, 87-93. [CrossRef]

25. Czarnowska-Kujawska, M.; Gujska, E.; Michalak, J. Folate determination in livers of different animal species. Czech J. Food Sci. 2020, 38, 43-48. [CrossRef]

26. Winkels, R.M.; Brouwer, I.A.; Siebelink, E.; Katan, M.B.; Verhoef, P. Bioavailability of food folates is $80 \%$ of that of folic acid. Am. J. Clin. Nutr. 2007, 85, 465-473. [CrossRef]

27. Nohr, D.; Biesalski, H.K. 'Mealthy' food: Meat as a healthy and valuable source of micronutrients. Animal 2007, 1, 309-316. [CrossRef]

28. German Society of Nutrition. Nutrition Report; DGE: Bonn, Germany, 2004.

29. Konings, E. Validated liquid chromatographic method for determining folates in vegetables, milk powder, liver, and flour. J. AOAC Int. 1999, 82, 119-127. [CrossRef] [PubMed]

30. Pffeifer, C.M.; Rogers, L.M.; Gregory, J.F. Determination of folate in cereal-grain products using tri-enzyme extraction and combined affinity and reversed-phase liquid chromatography. J. Agric. Food Chem. 1997, 45, 407-413. [CrossRef]

31. Jastrebova, J.; Witthöft, C.; Granath, A.; Svensson, U.; Jägerstad, M. HPLC determination of folates in raw and processed beetroots. Food Chem. 2003, 80, 579-588. [CrossRef]

32. Czarnowska, M.; Gujska, E. Effect of freezing technology and storage conditions on folate content in selected vegetables. Plant Foods Hum. Nutr. 2012, 67, 401-406. [CrossRef] [PubMed]

33. Blakley, R.L. The biochemistry of folic acid and related pteridines. In North-Holland Research Monographs; North-Holland Publishing Company: Amsterdam, The Netherlands, 1969; pp. 1-570.

34. Vahteristo, L.; Ollilainen, V.; Varo, P. HPLC determination of folate in liver and liver products. J. Food Sci. 1996, 61, 524-526. [CrossRef]

35. Delchier, N.; Ringling, C.; Maingonnat, J.; Rychlik, M.; Renard, K.M.G.C. Mechanisms of folate losses during processing: Diffusion vs. heat degradation. Food Chem. 2014, 157, 439-447. [CrossRef] [PubMed]

36. Gujska, E.; Michalak, J.; Klepacka, J. Folates stability in two types of rye breads during processing and frozen storage. Plant Foods Hum. Nutr. 2009, 64, 129-134. [CrossRef]

37. Delchier, N.; Ringling, C.; Le Grandois, J.; Aoudé-Wernerd, D.; Gallande, R.; Georgé, S.; Rychlik, M.; Renard, C.M.G.C. Effects of industrial processing on folate content in green vegetables. Food Chem. 2013, 139, 815-824. [CrossRef]

38. Hefni, M.; Witthöft, C. Folate content in processed legume foods commonly consumed in Egypt. LWT-Food Sci. Technol. 2014, 57, 337-343. [CrossRef]

39. Bureau, S.; Mouhoubi, S.; Touloumet, L.; Garcia, L.; Moreau, F.; Bédouet, V.; Renard, C.M.G.C. Are folates, carotenoids and vitamin $\mathrm{C}$ affected by cooking? Four domestic procedures are compared on a large diversity of frozen vegetables. LWT-Food Sci. Technol. 2015, 64, 735-741. [CrossRef]

40. Pan, Z.; Sun, Y.; Zhang, F.; Guo, X.; Liao, Z. Effect of thermal processing on carotenoids and folate changes in six varieties of sweet potato (Ipomoes batata L.). Foods 2019, 8, 215. [CrossRef] [PubMed]

41. Delchier, N.; Herbig, A.L.; Rychlik, M.; Renard, C.M.G.C. Folates in fruits and vegetables: Contents, processing and stability. Compr. Rev. Food Sci. Food Saf. 2016, 15, 506-528. [CrossRef]

42. Neetoo, H.; Chen, H. Alternative food processing technologies. In Food Processing: Principles and Applications; Clark, S., Ed.; John Wiley \& Sons, Ltd.: Hoboken, NJ, USA, 2014; pp. 137-169.

43. Baldwin, D.E. Sous vide cooking: A review. Int. J. Gastron. Food Sci. 2012, 1, 15-30. [CrossRef]

44. Głuchowski, A.; Czarniecka-Skubina, E.; Wasiak-Zys, G.; Nowak, D. Effect of various cooking methods on technological and sensory quality of atlantic salmon (Salmo salar). Foods 2019, 8, 323. [CrossRef] [PubMed]

45. Modzelewska-Kapituła, M.; Pietrzak-Fiećko, R.; Tkacz, K.; Draszanowska, A.; Więk, A. Influence of sous vide and steam cooking on mineral contents, fatty acid composition and tenderness of semimembranosus muscle from Holstein-Friesian bulls. Meat Sci. 2019, 157, 1-8. [CrossRef]

46. Isleroglu, H.; Kemerli, T.; Kaymak-Ertekin, F. Effect of steam-assisted hybrid cooking on textural quality characteristics, cooking loss, and free moisture content of beef. Int. J. Food Prop. 2015, 18, 403-414. [CrossRef]

47. Modzelewska-Kapituła, M.; Dąbrowska, E.; Jankowska, B.; Kwiatkowska, A.; Cierach, M. The effect of muscle, cooking method and final internal temperature on quality parameters of beef roast. Meat Sci. 2012, 91, 195-202. [CrossRef] 
48. Petersen, M.A. Influence of sous-vide processing, steaming and boiling on vitamin retention and sensory quality in broccoli florets. Zeitschrift Lebensmittel-Untersuchung Forschung 1993, 197, 375-380. [CrossRef]

49. Zhuang, H.; Savage, E.M. Validation of a combi oven cooking method for preparation of chicken breast meat for quality assessment. J. Food Sci. 2008, 73, 424-430. [CrossRef]

50. Aramouni, F.M.; Godber, J.S. Folate losses in beef liver due to cooking and frozen storage. J. Food Qual. 1991, 14, 357-365. [CrossRef]

51. Johansson, M.; Jägerstad, M.; Frølich, W. Folates in lettuce: A pilot study. Scand. J. Food Nutr. 2007, 51, 22-30. [CrossRef]

52. Maharaj, P.P.P.; Prasad, S.; Devi, R.; Gopalan, R. Folate content and retention in commonly consumed vegetables in the South Pacific. Food Chem. 2015, 182, 327-332. [CrossRef] [PubMed]

53. Hefni, M.; Öhrvik, V.; Tabekha, M.; Witthöft, C. Folate content in foods commonly consumed in Egypt. Food Chem. 2010, 121, 540-545. [CrossRef]

54. Vahteristo, L.; Lehikoinen, K.; Ollilainen, V.; Varo, P. Application of an HPLC assay for the determination of folate derivatives in some vegetables, fruits and berries consumed in Finland. Food Chem. 1997, 59, 589-597. [CrossRef]

(C) 2020 by the authors. Licensee MDPI, Basel, Switzerland. This article is an open access article distributed under the terms and conditions of the Creative Commons Attribution (CC BY) license (http://creativecommons.org/licenses/by/4.0/). 